\title{
Evidence in support of gene regulatory hypothesis: Gene expression profiling manifests homeopathy effect as more than placebo
}

\author{
Santu Kumar Saha1, Sourav Roy ${ }^{2}$ and Anisur Rahman Khuda-Bukhsh ${ }^{1}$
}

${ }^{1}$ Cytogenetics and Molecular Biology Laboratory, Univ. of Kalyani, West Bengal, India.

2Depart. Entomology and Inst. Integrative Genome Biology, Univ. of California, USA.

\begin{abstract}
Background: Use of ultra-high diluted remedies in homeopathy and their claimed efficacy in curing diseases has been challenged time and again by non-believers despite many evidencebased positive results published in favor of their efficacy in curing/ameliorating disease symptoms. Aims: To test the ability of ultra-high diluted homeopathic remedies beyond Avogadro's limit, if any, in manifesting gene modulating effects in controlled in vitro experimental model. Methods: Since cancer cells manifest aberrant epigenetic gene expressions, we conducted global microarray gene expression profiling of HeLa cells (an established epigenetic model of HPV18 positive cell line) treated with two different potentized homeopathic remedies, namely, Condurango 30c and Hydrastis canadensis 30C (used in the treatment of cancer), as compared to that of placebo (succussed alcohol 30c). Results: Data revealed distinctly different expression patterns of over 100 genes as a consequence of treatment with both homeopathc remedies compared to placebo. Conclusion: Results indicate that action of the potentized drugs was "more than placebo" and these ultra-highly diluted drugs acted primarily through modulation of gene expression.
\end{abstract}

Key words: Gene regulatory hypothesis, DNA microarray profile, potentized remedies.

\section{Introduction}

Homeopathy is one of the most widely practiced controversial modes of treatment as it uses extremely diluted remedies in micro-doses to alleviate patients' complaints. Despite being used for centuries with great effect, non-believers of homeopathy mainly ask two questions: (a) as drugs diluted beyond Avogadro's limit (6.023 x $10^{23}$ ) are not expected to contain even one single molecule of the original drug substance, how can the homeopathic medicines then be physical-chemically different from "vehicle" ethanol, and claimed to be effective in curing many diseases? (b) What might the mechanism of action of these ultra-highly diluted remedies be?

In this report, we present gene expression profiling results that give strong support to a hypothesis proposed by Khuda-Bukhsh [1, 2], to wit, that potentized homeopathic drugs act through regulation of gene expression. Thangapazham et al. [3], in turn, apparently failed to find changes in gene expression induced by homeopathic drugs used in in vitro experiments with human breast cancer cells MDA-MB-231, human prostate cancer cells DU-145 and LNCaP, and rat prostate cancer cells MAT-LyLu treated with some potentized homeopathic remedies like Conium maculatum, Sabal serrulata, Thuja occidentalis, Asterias rubens, and Phytolacca decandra in dilutions 30c, 200c and 1,000c, and Carcinosinum (1,000 c) although they 
had found in an earlier in vivo study reduction in the number and size of cancer nodules supported by histological analysis in prostate cancer MAT-LyLu cell-injected Copenhagen rats given homeopathic treatment containing Thuj, Con, Sabal serrulata, and in MAT-LyLu cell with Carc [4]. However, the authors did not conduct gene expression studies of any signal proteins in these rats in vivo, where modulation of certain gene expression would be expected.

The controversy surrounding research in homeopathy moves along two different directions. On the one hand, the mechanism of action of the potentized homeopathic remedies diluted beyond Avogadro's limit remains an open research problem, which has received widespread attention from the research community, and many competing hypotheses have been proposed. On the other hand, some studies that indicate homeopathy is no better than placebo, which thus makes any claim about the mechanism of action of homeopathic drugs null and void. There have been many results highly critical of homeopathy. For example, The Lancet of August 27, 2005 featured an article that was highly dismissive of homeopathy [5] along with a press release: "homeopathy is no better than placebo". The meta-analysis was accompanied by a short, anonymous editorial entitled 'The end of homoeopathy'. This resulted in the eruption of a ravaging controversy: whether homeopathy is really better than placebo or not, culminating in a debate in the British Parliament [6]. Homeopathy was decried and its use as a beneficial and scientifically proven mode of treatment was voted against. However, most clinical research conducted with homeopathic medicines has shown positive results [7]. Biological activities of ultra-high diluted potentized homeopathic remedies have also been confirmed by basic research studies with respect to a multitude of scientifically accepted protocols, both in animals and plants in vivo and in vitro [8]. Nevertheless, the argument persisted, as ultra-highly diluted homeopathic medicines are supposed to possess "nothing" in terms of the original drug molecules, and as such their effect on biological systems was unacceptable until recently. During the last few years, presence of "nanoparticles" of the starting materials, even at extremely high dilutions, has been reported [9, 10]. Moreover, Montagnier [11] countered through experiments that "high dilutions of something are not 'nothing', they are water structures which mimic the original molecules".

We decided to use one of the most modern tools, global microarray profiling of genes, to verify whether the effects of ultra-highly diluted homeopathic drugs on the expression profile of genes were distinctly different compared to "placebo". DNA microarrays are widely used to measure the expression levels of large numbers of genes simultaneously, with the aid of selective probes under highly stringent conditions. Gene expression profiling experiments are specially effective for monitoring the expression levels of thousands of genes to study the effects of certain treatments, for example, to identify genes whose expression change in response to pathogens or drugs, by comparing the gene expression in the infected and drug-treated cells or tissues [12].

\section{Materials and methods}

The aim of the present study was, therefore, to find out whether the global gene expression profiles in cancer cell line, HeLa (an established epigenetic model of HPV18 positive cell line) differed significantly, in quantitative as well as qualitative terms, after treatment with 2 homeopathic remedies used against cancer [13-15], namely, Condurango 30c and Hydrastis canadensis 30c (both diluted 10-60 times, much above Avogadro's limit) compared to ethanol 30c, (placebo, prepared from the same stock of $70 \%$ alcohol giving 10 jerks at each step in the same manner as the verum was potentized). Affymetrix Gene Chip Human Primeview gene expression arrays were used for this purpose.

Cervical cancer cell line HeLa was obtained at National Centre for Cell Science, Pune. The cells were routinely maintained in Dulbecco's Modified Eagle's Medium supplemented with 10\% FBS and 1\% antibiotic at $37{ }^{\circ} \mathrm{C}$ in a humidified incubator containing $5 \% \mathrm{CO}_{2}$. The cells were plated one day before treatment. $4 \%$ (v/v) of drugs and "placebo" (succussed ethanol 30c, 10 jerks at each step of dilution) were added to the cell 
cultures and kept for $48 \mathrm{hr}$. Cells without any treatment in the normal medium were considered as negative control.

Separate groups of cells were subjected to treatment with Cond 30c, Hydr 30c, and succussed alcohol placebo. The cells were sent to iLife Discoveries, Gurgaon, India for providing us global microarray data conducted on Affymetrix platform, using 25-mer probes. The total number of probes detected for the experiment was 49,395; hybridization was performed at $45^{\circ} \mathrm{C}$ for $16 \mathrm{hrs}$ at $60 \mathrm{rpm}$.

Slides were scanned with $30007 \mathrm{G}$ microarray scanner and raw data sets were extracted from the Cel (raw intensity) files. Microarray data analysis, differential gene expression analysis, fold change analysis and cluster analysis were performed using GeneSpring GX12.5 software.

\section{Results and discussion}

Microarray data analyses showed that out of a total of 40,678 genes, for which probe sets remained after data processing, normalization and quality control, 6,024 were differentially expressed at a p-value cutoff of 0.05 , in a one-way ANOVA. The expression levels of the genes in the cells were treated with Hydr 30c (Set I) and Cond 30c (Set II) were compared to the levels in the untreated (control) as well as succussed ethanol 30c (placebo) treated cells (Set III). Using a cutoff of 1.5 folds it was observed that in Set I, 3 genes each were upand down-regulated when compared to the control as well as Set III samples. Similarly, there were 2 genes in Set II that were up-regulated by at least 1.5 folds when compared to the two sets mentioned above, whereas 122 genes were down-regulated by $\geq 1.5$ folds. Two and 10 genes were up- and down-regulated by $\geq 1.5$ folds, respectively, in both sets (Set I and Set II) when compared to the control as well as Set III. In addition, there were another 23 genes in Set I and 12 genes in Set II that were differentially expressed by $\geq 1.5$ folds, when compared to Set III. Upon comparing the expression levels of genes in Set I and Set II, it was observed that for 36 genes, there were $\geq 1.5$ fold differences in expression between the 2 treatments. These findings suggest that the drugs did not only affect the gene expression, but also that the effect of one drug was different from the other in a number of genes.

The findings of the present study clearly demonstrate that the expression profiles of certain genes of the drugtreated HeLa cells were significantly different from that of the placebo treated cells. This suggests that both drugs and placebo differed in their ability to trigger gene responses, some of which were implicated in cancer. Thus, although the drugs were ultra highly diluted, they still retained the ability to trigger gene responses in a cascade of reactions, diving support to Khuda-Bukhsh's hypothesis[1-2]. Epigenetic modifications are a hallmark of cancer, and a large number of genes remain in modified state of expression in cancer cells. Both $H y d r$ [13, 15] and Cond [14, 15] had been previously reported to induce apoptosis in cancer cells, while "placebos" do not exhibit this property. Therefore, it is logical to infer that homeopathic remedies contain some form of molecular imprints of the original drug substance [16], while the "placebo", in the absence of such imprints, fails to elicit the required effect.

Incidentally, ultra-highly diluted preparations of glucose 30c, Arsenicum album 30c, and Arnica montana 30c were shown to induce gene modulatory effects in bacteria, E. coli and yeast Saccraromyces cerevisiae, either subjected to insult with sodium arsenite or UV-irradiation [17-19]. Those authors [17-19] explained that the potentized homeopathic remedies carry specific "signals"/"information" that can be identified by certain cell receptors. Those "signals" may act as a "trigger" for turning "on" or "off" some relevant genes, initiating a cascade of gene actions, while the "placebo" failed to elicit any such favorable responses. It has been previously documented that administration of a potentized homeopathic drug altered the expressions of a large number of signal proteins in mice induced to develop skin cancer [20].

The results of the present study, therefore, contribute to support the gene regulatory hypothesis proposed by Khuda-Bukhsh [1,2]. Further studies are needed to ascertain the ability of Cond 30c, if any, to modulate 
activities like DNA methylation/demethylation and histone acetylation/deacetylation, 2 hallmarks of epigenetic modifications, to produce additional support to the gene regulatory hypothesis.

\section{Author contributions}

ARK-B conceptualized and designed the experiments, SS performed the experiments, SR analyzed and interpreted the microarray data, ARK-B and SR wrote the manuscript.

\section{References}

[1] Khuda-Bukhsh AR. Potentized homeopathic drugs act through regulation of gene expression: a hypothesis to explain their mechanism and pathways of action in vivo. Comp Ther Med 1997; 5: 43-46.

[2] Khuda-Bukhsh AR. Towards understanding molecular mechanisms of action of homeopathic drugs: an overview. Mol Cell Biochem 2003;253: 339-45.

[3] Thangapazham RL, Gaddipati JP, Rajeshkumar NV, et al. Homeopathic medicines do not alter growth and gene expression in prostate and breast cancer cells in vitro. Integr Cancer Ther 2006; 5:356-61.

[4] Jonas WB, Gaddipati JP, Rajeshkumar NV, et al. In vitro and in vivo assessment of homeopathic treatment for prostate cancer. Paper presented at: Society of Integrative Oncology First International Conference; November 18, 2004; New York, NY.

[5] Shang A, Huwiler-Müntener K, Nartey L, et al. Are the clinical effects of homoeopathy placebo effects? Comparative study of placebo-controlled trials of homoeopathy and allopathy. Lancet 2005; 366:726-32.

[6] U.K. Parliamentary Committee on Science and Technology: Evidence 2. 2010, available at http://www.publications.parliament.uk/pa/cm200910/cmselect/cmsctech/45/4502.htm.

[7] Clausen J, van Wijk R, Albrecht H. Review of the use of high potencies in basic research on homeopathy.Homeopathy 2011; 100:288-92.

[8] The HomBRex database 2012.http://www.carstens-stiftung.de/hombrex/index.php.

[9] Chikramane PS, Suresh AK, Bellare JR, et al. Extreme homeopathic dilutions retain starting materials: A nanoparticulate perspective. Homeopathy 2010; 99: 231-42.

[10] Bhattacharyya SS, Mandal SK, Biswas R, et al.In vitro studies demonstrate anticancer activity of an alkaloid of the plant Gelsemium sempervirens.Exp Biol Med (Maywood) 2008; 233:1591-601.

[11] Montagnier L. Newsmaker interview: Luc Montagnier. French Nobelist escapes 'intellectual terror' to pursue radical ideas in China. Interview by Martin Enserink.Science 2010; 330:1732.

[12] Adomas A, Heller G, Olson A, et al. Comparative analysis of transcript abundance in Pinus sylvestris after challenge with a saprotrophic, pathogenic or mutualistic fungus". Tree Physiol 2008;28: 885-897.

[13] Saha SK, Sikdar S, Mukherjee A, et al. Ethanolic extract of Goldenseal, Hydrastis canadensis has demonstrable chemopreventive effects on HeLa cells in vitro: Drug-DNA interaction with calf thymus DNA as target. Environ Toxicol Pharmacol 2013; 36: 202-214.

[14] Mitsuhashi $\mathrm{H}$ et al. Condurango glycoside compounds processes for their preparation, antitumor agents comprising them and compositions. United States Patent 1984. 
[15] Boericke W. Pocket manual of homeopathic material medica \& repertory. reprint edn 2004. B. Jain Publishers (P) Ltd, India. 2002: 514.

[16] Davenas E, Beauvais F, Amara J, et al.Human basophil degranulation triggered by very dilute antiserum against IgE.Nature1988; 333:816-8.

[17] Saha SK, Das S, Khuda-Bukhsh AR.Phenotypic evidence of ultra-highly diluted homeopathic remedies acting at gene expression level: a novel probe on experimental phage infectivity in bacteria. Zhong Xi Yi Jie He Xue Bao 2012; 10:462-70.

[18] Das S, Saha SK, De A, et al. Potential of the homeopathic remedy, Arnica Montana 30C, to reduce DNA damage in Escherichia coli exposed to ultraviolet irradiation through up-regulation of nucleotide excision repair genes.Zhong Xi Yi Jie He Xue Bao 2012;10:337-46.

[19] Das D, De A, Dutta S, et al.Potentized homeopathic drug Arsenicum Album 30C positively modulates protein biomarkers and gene expressions in Saccharomyces cerevisae exposed to arsenate.Zhong Xi Yi Jie He Xue Bao 2011;9:752-60.

[20] Khuda-Bukhsh AR, Bhattacharyya SS, Paul S, et al. Modulation of Signal Proteins: A Plausible Mechanism to Explain How a Potentized Drug SecaleCor 30C Diluted beyond Avogadro's Limit Combats Skin Papilloma in Mice. Evid Based Complement Alternat Med 2011;2011:286320.

\section{Evidências a favor da hipótese de regulação genética: determinação do perfil de expressão genética demonstra que o efeito da homeopatia é mais do que placebo}

\section{RESUMO}

Introdução: O uso de medicamentos homeopáticos ultra-diluídos e a sua presumível eficácia na cura de doenças têm sido reiteradamente contestados por céticos, apesar dos muitos resultados positivos, baseados em evidências, demonstrando a sua eficácia na cura/melhora de sintomas patológicos. Objetivos: Testar a possível capacidade de medicamentos homeopáticos diluídos além do limite de Avogadro para apresentar efeitos de modulação genética em modelo experimental in vitro. Métodos: Sendo que as células neoplásicas manifestam expressões epigenéticas aberrantes, investigamos através de micro-arranjo o perfil global de expressão genética de células HeLa (modelo epigenético já estabelecido de linhas celulares HPV18 positivas) tratadas com 2 medicamentos homeopáticos dinamizados, a saber, Condurango 30c e Hydrastis canadensis 30c (utilizados no tratamento de neoplasias) comparados com um placebo (álcool sucussionado 30c). Resultados: Os dados indicaram diferentes perfis de expressão em mais de 100 genes nas células tratadas com os medicamentos homeopáticos por comparação ao placebo. Conclusão: Os resultados indicam que o efeito dos medicamentos dinamizados foi "mais do que placebo" e que essa ação foi principalmente mediada por modulação da expressão genética.

Palavras-chave: Hipótese da regulação genética, micro-arranjo de DNA, medicamentos dinamizados. 


\title{
Evidencias a favor de la hipótesis de regulación genética: determinación de perfil de expresión genética demuestra que el efecto de la homeopatía es más que placebo
}

\begin{abstract}
RESUMEN
Introducción: El uso de medicamentos homeopáticos ultra-diluidos y a su presunta eficacia en la curación de enfermedades han sido reiteradamente cuestionados por escépticos, a pesar de los diversos resultados positivos, basados en evidencias, que demuestran su eficacia en la curación/mejoría de síntomas patológicos. Objetivos: Testear la posible capacidad de medicamentos homeopáticos diluidos más allá del límite de Avogadro de presentar efectos de modulación genética en modelo experimental in vitro. Métodos: Dado que las células neoplásicas manifiestan expresiones epigenéticas aberrantes, investigamos mediante chips de ADN el perfil global de expresión genética de células HeLa (modelo epigenético bien establecido de linajes celulares HPV18 positivos) tratadas con 2 medicamentos homeopáticos dinamizados, a saber, Condurango 30c e Hydrastis canadensis 30c (utilizados en el tratamiento de neoplasias) comparados con placebo (alcohol sucusionado 30c). Resultados: Los dados indicaron diferentes perfiles de expresión en más de 100 genes en las células tratadas con los medicamentos homeopáticos en comparación al placebo. Conclusión: Los resultados indican que el efecto de los medicamentos dinamizados fue "más que placebo" y que esta acción fue principalmente mediada por modulación de la expresión genética.
\end{abstract}

Palabras clave: Hipótesis de la regulación genética, chips de DNA, medicamentos dinamizados.

\section{(c)) BY-NC-ND Licensed to GIRI}

Support: Partial financial assistance to ARK-B for this work by Boiron Laboratories, Lyon, France, is sincerely acknowledged. The funding agency had no role in the study design, data collection or analysis, interpretation of data and writing of this manuscript.

Conflict of interest: authors declare there is no conflict of interest

Received: June 28 $8^{\text {th }}$ 2013; Revised: November 19th 2013; Published: December $18^{\text {th }} 2013$.

Correspondence author: Anisur R. Khuda-Bukhsh, University of Kalyani, India, prof arkb@yahoo.co.in

How to cite this article: Saha SK, Roy S, Khuda-Bukhsh AR. Evidence in support of gene regulatory hypothesis: Gene expression profiling manifests homeopathy effect as more than placebo. Int J High Dilution Res [online]. 2013 [cited YYYY Month dd]; 12(45): 162:167. Available from: http://www.feg.unesp.br/ ojs/index.php/ijhdr/article/view/635/684 